\title{
The isotope signature and distribution of particulate iron in the North Atlantic Ocean
}

Brandi N. Revels ${ }^{1}$, Daniel C. Ohnemus ${ }^{2,3}$, Phoebe J. Lam ${ }^{2}$, Tim M. Conway ${ }^{1}$ and Seth G. John ${ }^{1 *}$,

${ }^{1}$ Department of Earth and Ocean Sciences, University of South Carolina, Columbia, SC 29208, USA

${ }^{2}$ Department of Marine Chemistry and Geochemistry, Woods Hole Oceanographic Institution, Woods Hole, MA

02543, USA

${ }^{3}$ MIT-WHOI Joint Program in Oceanography, Woods Hole, MA 02543

*Corresponding author: sjohn@geol.sc.edu; Phone: +1 803-777-7052

Keywords: iron, isotopes, GEOTRACES, trace metal, biogeochemistry

\section{Abstract}

Iron (Fe) is a key micronutrient for life in the oceans. Particles play an important role in the marine biogeochemical cycling of $\mathrm{Fe}$ as a reservoir of marine Fe that may be directly accessible to phytoplankton, and as sources and sinks for seawater dissolved Fe. Here, we report the stable isotopic composition of $\mathrm{Fe}\left(\delta^{56} \mathrm{Fe}\right)$ in suspended $(0.8-51 \mu \mathrm{m})$ particles from the US GEOTRACES North Atlantic zonal transect, in order to facilitate a better understanding of the marine biogeochemical cycling of Fe. Data are presented both for a total digestion of the particles, and for "ligand-leachable" phases of Fe using a newlydeveloped $\mathrm{pH} 8$ oxalate-EDTA leach. For total particle digests, the mean $\delta^{56} \mathrm{Fe}$ across the whole North Atlantic was $0.08 \pm 0.09 \%$ ( 1 S.D.) which is equivalent to the isotope composition of known lithogenic Fe sources to the ocean. In contrast, ligand-leachable Fe was generally lighter than continental material with a mean $\delta^{56} \mathrm{Fe}$ of $-0.30 \pm 0.17 \%$ (1 S.D.). Our data also provides valuable insight into Fe biogeochemical cycling in several key regions. In the deep ocean, but above the depths where near-sediment nephloid layers are present, ligand-leachable Fe is isotopically lighter in the deep western basin compared to the deep central and eastern basin, suggesting differences in particle surface chemistry between resuspended seafloor sediments, which may predominate in the west, and Saharan dust that predominates in the central and eastern basins. Within a nephloid layer above reduced continental margin sediments in the eastern basin, below the Mauritanian upwelling region, we report the lowest particulate $\delta^{56} \mathrm{Fe}$ values for both total and ligand-leachable Fe, suggesting a transfer of isotopically light dissolved porewater $\mathrm{Fe}^{2+}$ to the particulate phase. In contrast, $\delta^{56} \mathrm{Fe}$ values within a nephloid layer near Bermuda are similar to values higher in the water column. Within a hydrothermal plume 
sampled at the TAG hydrothermal field on the mid-Atlantic Ridge, decreasing Fe concentration and $\delta^{56} \mathrm{Fe}$ with distance from the vent indicate the water-column precipitation of Fe oxyhydroxides within the plume. Comparison between total and ligand-leachable particulate $\mathrm{Fe}$ concentrations throughout the transect also provides useful biogeochemical information. In the chlorophyll maximum, a high proportion of $\mathrm{Fe}$ in the labile phase demonstrates a relative lack of lithogenic material, while the high proportion of labile Fe observed between 2000 to $4000 \mathrm{~m}$ depth to the west of the midAtlantic ridge suggests that hydrothermal oxyhydroxide particles can be transported thousands of kilometers away from vent sites. Throughout the North Atlantic, total and ligand-leachable $\mathrm{Fe}$ concentration and $\delta^{56} \mathrm{Fe}$ therefore provide a useful tool for studying the biogeochemical cycling of particulate Fe. 


\section{INTRODUCTION}

Dissolved iron $(\mathrm{Fe})$ is an essential micronutrient for phytoplankton, limiting growth over much of the surface ocean (e.g. Moore et al., 2002). Dissolved Fe is often depleted by biological uptake in the surface ocean, and particles are important reservoir of Fe that can be either directly available to phytoplankton or can be made bioavailable by dissolution. Transfer to the particulate phase is also the primary pathway by which bioavailable $\mathrm{Fe}$ is lost from the ocean, either after incorporation into plankton that sink out of the surface ocean or by precipitation (scavenging) onto the surface of sinking particles. As both a source and a sink for dissolved $\mathrm{Fe}$ in the oceans, particles therefore play an important role in marine biogeochemical cycles.

Marine particles are often broadly classified as biogenic, lithogenic, or authigenic, with each of these particle types likely to have differing biogeochemistries. Biogenic particles include phytoplankton which directly assimilate dissolved Fe from seawater into proteins and enzymes, as well as the Fe contained in marine organisms further up the food chain (e.g heterotrophs) and biological detritus. Lithogenic particles include aerosol dust delivered to the surface ocean and resuspended seafloor sediments. Authigenic minerals include $\mathrm{Fe}$ oxyhydroxides which form in situ when dissolved $\mathrm{Fe}^{2+}$ is released into seawater and then subsequently oxidized to insoluble Fe(III) hydroxides, for example from reducing continental margin sediments or in hydrothermal plumes.

In the last five years, the first measurements have been made of the dissolved Fe stable isotopic signature ( $\left.\delta^{56} \mathrm{Fe}\right)$ of seawater (e.g. Conway et al., 2013; Lacan et al., 2010). Seawater dissolved $\delta^{56} \mathrm{Fe}$ measurements have been used to trace sources of $\mathrm{Fe}$ into the oceans, including both reductive and non-reductive dissolution of continental margin sediments (Conway and John, 2014; Homoky et al., 2013; John et al., 2012; Radic et al., 2011). Seawater dissolved $\delta^{56} \mathrm{Fe}$ in the North Atlantic has been interpreted as reflecting aerosol Fe deposition to the surface ocean (John and Adkins, 2012) or a mixture of various sources of $\mathrm{Fe}$ to the oceans (Conway and John, 2014), and differences between dissolved $\delta^{56} \mathrm{Fe}$ in the North Atlantic and Southern Ocean (Lacan et al., 2008) suggest 
regional to global variability in Fe cycling. To our knowledge, published measurements of total marine particulate $\delta^{56} \mathrm{Fe}$ are confined to several measurements from the equatorial Pacific (Radic et al., 2011), measurements from the Baltic Sea (Gelting et al., 2010; Staubwasser et al., 2013), and measurements of hydrothermal plume particles from both the TAG hydrothermal field in the North Atlantic and the hydrothermal fields at $5^{\circ} \mathrm{S}$ on the Mid Atlantic Ridge (Bennett et al., 2008; Severmann et al., 2004). Hydrothermal particles from the two hydrothermal vent sites studied in the North Atlantic are found to be either isotopically heavier (Severmann et al., 2004) or lighter (Bennett et al., 2009) than hydrothermal fluids at the same location, reflecting the variability in vent chemistry between different sites. This leads to uncertainty about whether hydrothermal Fe which remains in the dissolved phase is isotopically heavy or isotopically light compared to vent fluids, and therefore to uncertainty about whether the global average hydrothermal vent flux to the ocean is isotopically heavy or isotopically light compared to seawater. Fe to the ocean. $\delta^{56} \mathrm{Fe}$ in particles in the equatorial Pacific range in from 0 to $+0.4 \%$, which is similar to the average continental $\delta^{56} \mathrm{Fe}$ of $+0.1 \%$, with variations possibly resulting from the presence of hydrothermal particles (Radic et al., 2011).

All previous studies of particulate $\delta^{56} \mathrm{Fe}$ have employed a total particle digestion; however, it is unlikely that this total phase represents the particulate Fe available to exchange with seawater, given that particulate $\mathrm{Fe}$ is present as a mixture of a range of insoluble refractory and more-soluble 'labile' phases. Although most particulate $\mathrm{Fe}$ is thought to be present in these refractory crystalline silicates, their low solubility means that the Fe is typically not considered 'bioavailable' or able to interact with phytoplankton or the dissolved Fe reservoir. Previously, leaches have been developed to access various 'labile' phases of Fe, without dissolving silicate-bound Fe (e.g. Tessier et al., 1979). Similar leaches have been specifically applied to dissolving the 'bioavailable' labile phases of Fe from suspended marine particles (e.g. Berger et al., 2008, and references therein). Applying such leaches to isotopic studies, however, remains a challenge. All labile-phase leaches are necessarily operationally defined, and it is not always possible to be sure that the phases of interest have been entirely dissolved while other phases have not been dissolved at all. If various Fe-containing phases have different 
$\delta^{56} \mathrm{Fe}$ signatures, such incongruent dissolution may lead to a mixing of isotope signals from different pools of Fe. Similarly, incongruent dissolution of phases raises the possibility that the isotope signature of the phase of interest may be overprinted by a kinetic isotope fractionation during dissolution.

Despite these methodological challenges, we are motivated to seek a leach for labile Fe concentration $([\mathrm{Fe}])$ and $\delta^{56} \mathrm{Fe}$ because this $\mathrm{Fe}$ is the phase most likely to interact with the dissolved Fe reservoir. In hydrothermal plumes, possible sources of labile iron include iron oxyhydroxides which precipitate when warmer, reducing hydrothermal fluids mix with cooler, oxic seawater, and iron sulfides which may form during mixing or may form when hydrothermal fluids are still underground, and iron oxides formed by oxidation of sulfide particles. Near continental margins, particulate Fe may include resuspended sediments. In locations where sediment pore waters are reducing, the labile particulate Fe may include a component of Fe oxyhydroxides that precipitated when reduced $\mathrm{Fe}^{2+}$ from sediment pore waters mixed with oxic seawater. In the surface ocean, labile Fe may include biological Fe (e.g. plankton) as well as Fe that adsorbed or precipitated onto the surface of organic or inorganic particles, as well as amorphous Fe minerals and Fe loosely bound or adsorbed to clay particles.

Here, we present data on suspended $(0.8-51 \mu \mathrm{m})$ particles collected from large-volume in-situ pump filtration on the U.S. GEOTRACES North Atlantic zonal transect completed in 2010-11. These samples are treated with a new leach designed to dissolve the "ligandleachable" labile phases of $\mathrm{Fe}$, for which we report both the concentration $\left(\left[\mathrm{Fe}_{\text {labile }}\right]\right)$ and iron stable isotope ratio $\left(\delta^{56} \mathrm{Fe}_{\text {labile }}\right)$. In addition, we present concentration $\left(\left[\mathrm{Fe}_{\text {total }}\right]\right)$ and stable isotope $\left(\delta^{56} \mathrm{Fe}_{\text {total }}\right)$ for total digestions of the suspended particles. These data are interpreted in order to better understand the sources and biogeochemical cycling of particulate Fe in the North Atlantic.

\section{MethodS}

\subsection{Sample collection}


The oxalate-ethylenediaminetetraacetic acid (oxalate-EDTA) leaching method was tested on material from a $275 \mathrm{~m}$ deep sediment trap located in the Cariaco Basin $\left(10.5^{\circ} \mathrm{N}, 64.7\right.$ ${ }^{\circ} \mathrm{W}$ ), sampled as part of the CARIACO program on March 14th, 1997 (Martinez et al., 2007). These sediment trap samples were freeze-dried and homogenized after collection and were reported to contain $48.23 \%$ biogenic material and $24.99 \%$ lithogenic material by weight, with an Fe concentration of 1.26\% (Martinez et al., 2007).

North Atlantic samples were collected on the US GEOTRACES North Atlantic A03 transect in 2010 (Lisbon to Cape Verde) and 2011 (Woods Hole to Cape Verde) (Fig. 1). Size-fractionated particulate samples $(>51 \mu \mathrm{m}$ and $0.8-51 \mu \mathrm{m})$ were collected using insitu battery powered McLane pumps as described in Ohnemus and Lam (this issue). Particle subsamples of the suspended phases $(0.8-51 \mu \mathrm{m}$ size fraction) representing $1 / 16$ of the $142 \mathrm{~mm}$ diameter $0.8 \mu \mathrm{m}$ polyethersulfone (PES, Supor800) filters ( $30 \mathrm{~L}$ filtered equivalent) were cut using a ceramic rotary blade. Separate subsamples were processed for total digests using the "Piranha" digest technique (Ohnemus et al., this issue) and for the ligand-labile phase using an oxalate-EDTA leach as described herein.

\subsection{Equipment and Reagents}

All leaching and isotopic work was undertaken under ultra-low penetration air (ULPA) filtration at the University of South Carolina using high-purity acids, obtained from either double quartz distillation (DQD; hydrochloric) or PFA Teflon distillation (TD; nitric and hydrofluoric). All plasticware was rigorously acid cleaned prior to use, following procedures detailed in Conway et al. (2013) and samples were handled with polyethylene gloves. Total particle digestions were performed in HEPA-filtered fume hoods at WHOI using Seastar Baseline ultrapure acids and reagents, as described in Ohnemus and Lam (this issue).

\subsection{Sample preparation}

In order to extract only the labile "ligand-leachable" Fe phases from North Atlantic GEOTRACES particle samples, an oxalate-EDTA leaching solution at $\mathrm{pH} 8$ was used. This leaching solution was based on methods designed to remove surface-bound Fe from 
phytoplankton (Tovar-Sanchez et al., 2003). Oxalate in the leach facilitates dissolution of inorganic Fe oxyhydroxides by binding and liberating surface-bound $\mathrm{Fe}$ atoms, and EDTA is added to ensure that all dissolved Fe remains in solution. However, unlike Tovar-Sanchez et al., we also hoped to capture biogenic phases of Fe with our leach. We therefore omitted $\mathrm{NaCl}$ from the solution, which Tovar-Sanchez et al. used to maintain high ionic strength which prevents bursting of phytoplankton cells. We applied the leach at $90^{\circ} \mathrm{C}$ which is considered high enough to denature proteins making biogenic $\mathrm{Fe}$ available for dissolution (Berger et al., 2008). Also, longer leaching times of up to $24 \mathrm{hr}$ were tested. The oxalate leaching solution contained $0.1 \mathrm{~mol} \mathrm{~L}^{-1}$ oxalic acid (Alfa Aesar 99.5\%, \#423150050, Lot A0284360) and $0.05 \mathrm{~mol} \mathrm{~L}^{-1}$ EDTA (Fisher BioReagents, tetraacetic acid form, \#BP118-500, Lot 095965A) in ultrapure water, and was adjusted to pH 8 with NaOH (EMD ACS grade, \#SX0593-1, Lot UN1832). The oxalate-EDTA solution was cleaned following the methods of Tovar-Sanchez et al. (2003) which involved reduction of $\mathrm{Fe}$ to $\mathrm{Fe}$ (II) with hydroxylamine $\mathrm{HCl}$, binding of $\mathrm{Fe}(\mathrm{II})$ to 1,10 phenanthroline, and extraction of the Fe(II)-1,10-phenanthroline complex into 1,2dichloroethane. Both the Fe concentration and $\delta^{56} \mathrm{Fe}$ of the oxalate-EDTA leaching solution were tested both before and after the published cleaning methods had been applied.

Both GEOTRACES North Atlantic particulate samples and experimental Cariaco Basin samples were processed in a similar fashion. Cariaco Basin sediment trap samples homogenized by grinding with a mortar and pestle, then placed in a $15 \mathrm{~mL}$ polyethylene centrifuge tube with $5-10 \mathrm{mg}$ of dried sediment trap material added to $5 \mathrm{~mL}$ of the oxalate-EDTA leach. North Atlantic GEOTRACES samples were processed by placing $1 / 32^{\text {nd }}$ of the Supor filter in a $2 \mathrm{~mL}$ polyethylene vial with $1 \mathrm{~mL}$ oxalate-EDTA leach. Samples were then put in a $90^{\circ} \mathrm{C}$ oven for $2 \mathrm{hr}$ (GEOTRACES samples) or for $10 \mathrm{~min}, 2$ $\mathrm{hr}$, or $24 \mathrm{hr}$ (Cariaco samples). At the end of the leaching period, the leachate was taken up with a $2 \mathrm{~mL}$ polypropylene/polyethylene syringe (Norm-Ject) and passed through an uncleaned $4 \mathrm{~mm}$ polypropylene syringe filter with a $0.45 \mu \mathrm{m}$ PTFE membrane (Whatman). 
Samples were prepared for elemental analysis by dilution to $5 \%$ in $0.1 \mathrm{~mol} \mathrm{~L}^{-1} \mathrm{HNO}_{3}$, and concentrations of $\mathrm{Fe}$ were determined by reference to concentration standards in a similar matrix by Thermo Element II sector field inductively coupled plasma mass spectrometry (ICPMS) using a quartz cyclonic spray chamber at the University of South Carolina Center for Elemental Mass Spectrometry (CEMS). An aliquot containing $100 \mathrm{ng}$ of Fe from each sample was then spiked in a 1:2 ratio with $200 \mathrm{ng}$ of Fe double-spike containing roughly equal amounts of ${ }^{57} \mathrm{Fe}$ and ${ }^{58} \mathrm{Fe}$ (Conway, 2013; John, 2012). The spiked sample was evaporated to dryness, reacted overnight at $120^{\circ} \mathrm{C}$ with $100 \mu \mathrm{L}$ of concentrated $\mathrm{HNO}_{3}$ and $100 \mu \mathrm{L}$ concentrated $\mathrm{H}_{2} \mathrm{O}_{2}$ to dissolve organics in the leachate, and dried down again. Samples were next reconstituted in $0.2 \mathrm{~mL} 10 \mathrm{~mol} \mathrm{~L}^{-1} \mathrm{HCl}+$ $0.001 \% \mathrm{v} / \mathrm{v} \mathrm{H}_{2} \mathrm{O}_{2}$ for anion exchange chromatography purification following a method slightly modified from previously published methods (Conway et al., 2013). Samples were loaded onto $135 \mu \mathrm{L}$ of AG-MP1 anion exchange resin, salts were eluted with 0.5 $\mathrm{mL} 10 \mathrm{~mol} \mathrm{~L}^{-1} \mathrm{HCl}+0.001 \% \mathrm{v} / \mathrm{v} \mathrm{H}_{2} \mathrm{O}_{2}, \mathrm{Cu}$ was eluted with $1.2 \mathrm{~mL} 5 \mathrm{~mol} \mathrm{~L}^{-1} \mathrm{HCl}+$ $0.001 \% \mathrm{v} / \mathrm{v} \mathrm{H}_{2} \mathrm{O}_{2}$, and $\mathrm{Fe}$ was eluted with $0.8 \mathrm{~mL} 1 \mathrm{~mol} \mathrm{~L}^{-1} \mathrm{HCl}$. This eluent was then evaporated to dryness and samples were reconstituted in $2 \mathrm{~mL} 0.1 \mathrm{~mol} \mathrm{~L}^{-1} \mathrm{HNO}_{3}$ for isotopic analysis.

Total digests of particle samples were prepared using the "Piranha digest" technique (Ohnemus et al., this issue) as described in Ohnemus and Lam (this issue). Briefly, filter subsamples were first digested in a 3:1 mixture of ultrapure concentrated $\mathrm{H}_{2} \mathrm{SO}_{4}: \mathrm{H}_{2} \mathrm{O}_{2}$, followed by a second digestion in a mixture of $4 \mathrm{~mol} \mathrm{~L}^{-1}$ each of ultrapure $\mathrm{HCl} / \mathrm{HNO}_{3} / \mathrm{HF}$. The dried final digested sample was brought up in $5 \% \mathrm{HNO}_{3}$. Fe was measured on an Element II sector field ICPMS using a quartz cyclonic spray chamber at the WHOI Plasma Facility. Concentrations were standardized using mixed external standards and ${ }^{115} \mathrm{In}$ as an internal drift monitor. The detection limit based on full process blanks was $27 \mathrm{pmol} \mathrm{L}^{-1} \mathrm{Fe}$ and analytical errors were $<5 \%$. For total digestion of Cariaco Basin samples at USC, $100 \mu \mathrm{g}$ of sample was reacted with $3.5 \mathrm{~mL}$ of a $3: 1$ mixture of concentrated $\mathrm{HF}: \mathrm{HNO}_{3}$ for 48 hours at $\sim 90^{\circ} \mathrm{C}$. Samples were then evaporated to dryness, dissolved with $1 \mathrm{~mL} 12 \mathrm{~mol} \mathrm{~L}^{-1} \mathrm{HCl}$ and evaporated to dryness, and twice dissolved with $1 \mathrm{~mL} 7.5 \mathrm{~mol} \mathrm{~L}^{-1} \mathrm{HNO}_{3}$ and evaporated to dryness. Subsamples following total digestion 
were spiked with double-spike in a 1:2 ratio and purified as described for ligandleachable labile samples above.

Fe stable isotopes ratios were determined using a Thermo Neptune multi collector ICPMS in CEMS in high-resolution mode, following analytical procedures developed for the analysis of stable isotopes in seawater (Conway et al., 2013). Briefly, samples were introduced using a borosilicate glass nebulizer, an Apex-Q (ESI) desolvating introduction system, without a desolvating membrane, and a jet interface with platinum Jet cone and an aluminum 'x-type' sampler cone. Samples were analyzed over 50 cycles of 4.2 seconds, with the first 12-15 cycles discarded to account for uptake and stabilization, leaving approximately 3 minutes per analysis. Isobaric interferences from $\mathrm{Cr}$ and $\mathrm{Ni}$ were corrected for by monitoring ${ }^{53} \mathrm{Cr}$ and ${ }^{60} \mathrm{Ni}$, respectively, and instrumental mass bias was corrected for using the double-spike technique following the iterative method of Siebert et al. (2001). Two IRMM-014 double spike mixtures with equivalent concentrations and sample-spike ratio to samples were analyzed with samples, and samples are expressed relative to the average isotopic ratio of these standards. Following Conway et al. (2013) and John (2012), we find that uncertainty on typical stable isotope measurements is dominated by internal analytical error, and so error in this study is expressed based on $2 \sigma$ standard internal error of MC-ICPMS analyses of samples and standards. Our reported error therefore represents only the internal analytical error for a processed sample, and does not include variability between different leaches or heterogeneity in sample loading on different portions of the filter. In addition to $\delta^{56} \mathrm{Fe}$, the double-spike method provides a very accurate measurement of sample/spike ratios, so the final reported concentration of ligand-leachable $\mathrm{Fe}$ was determined from these isotopic analyses, rather than from initial concentrations measured by SF-ICPMS.

Process blanks for the method, excluding the blank contributed by the leach, were $<5 \mathrm{ng}$, and $2 \sigma$ errors were typically 0.03 to $0.05 \%$. We report all Fe stable isotope ratios $\left(\delta^{56} \mathrm{Fe}\right)$ relative to the IRMM-014 isotope standard using delta notation: 


$$
\delta^{56} \mathrm{Fe}_{\text {sample }}(\%)=\left(\frac{\left({ }^{56} \mathrm{Fe} /{ }^{54} \mathrm{Fe}\right)_{\text {sample }}}{\left({ }^{56} \mathrm{Fe} /{ }^{54} \mathrm{Fe}\right)_{\text {IRMM }-014}}-1\right) 1000
$$

\section{RESULTS}

All measurements of Fe concentrations and $\delta^{56} \mathrm{Fe}$ have been submitted to the online data repository The Biological and Chemical Oceanography Data Management Office (BCODMO) for public distribution (http://www.bco-dmo.org/project/2066).

\subsection{Oxalate-EDTA Fe leach testing}

Two characteristics of the oxalate-EDTA leach were tested in order to ensure that it could be applied to natural samples. First, the Fe reagent blank in the leaching solution was measured to ensure that Fe added from the solution did not skew the $\delta^{56} \mathrm{Fe}$ signature of the sample. Second, tests were carried out to establish that particulate Fe was not significantly fractionated during oxalate-EDTA leaching. Prior to cleaning, the oxalateEDTA leach contained $\sim 300 \mathrm{ng} \mathrm{g}^{-1}$ of Fe. Before use on natural samples, the solution was purified according to the established procedure (Tovar-Sanchez et al., 2003, Section 2.3). Two batches of leach solutions were prepared this way, the first contained $25.0 \pm 0.5 \mathrm{ng}$ $\mathrm{g}^{-1} \mathrm{Fe}$ with a $\delta^{56} \mathrm{Fe}$ of $-3.62 \pm 0.17 \%$ ( $\left.1 \sigma \mathrm{SD}, \mathrm{n}=2\right)$, and the second contained $80.0 \pm 2.1$ ng g ${ }^{-1}$ Fe with a $\delta^{56} \mathrm{Fe}$ of $-0.37 \pm 0.17 \%$ ( $\left.1 \sigma \mathrm{SD}, \mathrm{n}=3\right)$. The first leach solution was used for samples from USGT stations 11-10, 11-16, and 10-9, while the second was used for all other samples. Corrections for the blank were made to all samples following an isotopic mass balance equation:

$$
\delta^{56} \mathrm{Fe}_{S}=\frac{\delta^{56} \mathrm{Fe}_{M} \otimes[\mathrm{Fe}]_{B}+\delta^{56} \mathrm{Fe} e_{M} \otimes[\mathrm{Fe}]_{S}-\delta^{56} \mathrm{Fe} e_{B} \otimes[\mathrm{Fe}]_{B}}{[\mathrm{Fe}]_{S}}
$$

where the subscripts $\mathrm{M}, \mathrm{S}$, and B refer to the measured, sample, and blank Fe concentrations or $\delta^{56} \mathrm{Fe}$, respectively. The error associated with the correction therefore 
depends both on the amount of Fe contributed from the blank, and the difference between the blank and sample $\delta^{56} \mathrm{Fe}$. Because both sample and blank Fe concentrations were determined with high accuracy by double-spike MC-ICPMS, the final error in $\delta^{56} \mathrm{Fe}_{\mathrm{S}}$ for the ligand-leachable fraction was determined based only on the analytical errors in $\delta^{56} \mathrm{Fe}_{\mathrm{M}}$ and $\delta^{56} \mathrm{Fe}_{\mathrm{B}}$, and the relative proportions of blank and total-measured $\mathrm{Fe}$.

The oxalate-EDTA leach was tested to ensure that kinetic isotope effects did not lead to Fe isotope fractionation during leaching (Fig. 2). Duplicate Cariaco sediment trap samples were leached for either $10 \mathrm{~min} ., 2 \mathrm{hr}$, or $24 \mathrm{hr}$ at $90^{\circ} \mathrm{C}$. The four samples treated for $10 \mathrm{~min}$. or $2 \mathrm{hr}$ leached similar quantities of Fe (11-18\%) and all had the same $\delta^{56} \mathrm{Fe}$ within $2 \sigma$ error ( +0.05 to $+0.09 \%$ ). After leaching for $24 \mathrm{hr}, 41 \%$ and $58 \%$ of $\mathrm{Fe}$ was leached from two samples with $\delta^{56} \mathrm{Fe}$ of +0.09 and $+0.21 \%$, respectively. Two total digestions with $\mathrm{HF}-\mathrm{HNO}_{3}$ of the Cariaco sediment trap materials yielded analytically indistinguishable $\delta^{56} \mathrm{Fe}$ within error of +0.19 and $+0.20 \%$ ( $( \pm 0.04 \% ; 2 \sigma)$. The fact that the heaviest $\delta^{56} \mathrm{Fe}$ was determined for the sample with the highest concentration of Fe in the leachate $(+0.21 \%, 58 \%)$ may be due to the particles containing a more labile Fe phase with $\delta^{56} \mathrm{Fe}$ near $+0.1 \%$, mixed with a similar quantity of isotopically-heavier refractory Fe. Alternatively, it could be due to a small kinetic isotope effect $(\sim 0.1 \%$ ) during leaching. The variability in $\delta^{56} \mathrm{Fe}$ for all four of the shorter leaches was similar within analytical error $(0.04 \%$ o $2 \sigma$ S.D. compared to internal analytical errors of 0.03 to $0.05 \%$ o $2 \sigma$ S.E.). This suggests that external reproducibility for our North Atlantic GEOTRACES samples is likely to be similar to the internal analytical error, although this was not verified using GEOTRACES samples. In contrast to the relatively small difference in $\delta^{56} \mathrm{Fe}$ between different leaches of our standard materials, variability in the fraction of $\mathrm{Fe}$ leached was much greater than our analytical error for Fe concentrations using the double-spike technique. This suggests that measurements of the concentration of Fe in the 'labile' particulate phase are only accurate to within roughly a factor of two, at least when the fraction of total Fe leached is low (less than $\sim 50 \%$ ). Based on these results, we chose to leach all GEOTRACES North Atlantic particulate samples for $2 \mathrm{hr}$ at $90^{\circ} \mathrm{C}$. This duration leached a smaller and more consistent amount of Fe than a $24 \mathrm{hr}$ leach, but was long enough to be applied more reproducibly than a $10 \mathrm{~min}$. leach. 


\subsection{Validity of the leach for natural samples}

In addition to experiments on Cariaco Basin sediment trap material, consideration of the ligand-leachable, total particulate [Fe], and $\delta^{56} \mathrm{Fe}$ of GEOTRACES samples from the North Atlantic provides further evidence that the oxalate-EDTA leach is an appropriate method to extract a meaningful labile or exchangeable $\delta^{56} \mathrm{Fe}$ from natural marine particles.

Firstly, for each sample, we calculated the fraction of total Fe which occurs in the labile phase $\left(f_{\text {labile }}\right)$, and, throughout the transect, we find that $f_{\text {labile }}$ is close to 1 in the chlorophyll maximum, suggesting that biogenic $\mathrm{Fe}$ is efficiently dissolved by this leach (Fig. 3). Similarly, flabile approaches 1 in the hydrothermal plume above the mid-Atlantic Ridge where particulate Fe is mostly Fe oxyhydroxides (Fig. 4). Further, the maxima in $f_{\text {labile }}$ at the chlorophyll maximum and hydrothermal plume correspond to regions of excess Fe over crustal ratios of Fe:Ti in total particulate digests (Ohnemus and Lam, this issue). Therefore, we suggest that the oxalate-EDTA leach dissolves Fe from both biogenic particles and authigenic Fe oxyhydroxides, two of the most important labile phases of $\mathrm{Fe}$ in the oceans.

Secondly, we examined the difference between $\delta^{56} \mathrm{Fe}_{\text {labile }}$ and $\delta^{56} \mathrm{Fe}_{\text {total }}\left(\Delta \delta^{56} \mathrm{Fe}_{\text {labile-total }}\right)$ as a function of the proportion of total particulate Fe that is labile (Fig. 5A). As flabile approaches 1, meaning that all of the particulate Fe was dissolved by the leach, $\Delta \delta^{56} \mathrm{Fe}_{\text {labile-total }}$ should approach zero. Indeed, we do observe an overall trend in $\Delta \delta^{56} \mathrm{Fe}_{\text {labile-total }}$ towards zero as flabile increases. However, it should be noted that some low-concentration samples have negative $\Delta \delta^{56} \mathrm{Fe}_{\text {labile-total }}$ even at $f_{\text {labile }}$ values close to 1 (down to $-0.4 \%$ ). Several samples have $\Delta \delta^{56} \mathrm{Fe}_{\text {labile-total }}$ values which are lower than would be predicted even if the labile phase were -3\% compared to the refractory phase, where $-3 \%$ is the approximate equilibrium fractionation between $\mathrm{Fe}(\mathrm{II})$ and $\mathrm{Fe}(\mathrm{III})$ at environmental temperatures (Welch et al., 2003) and therefore represents an upper limit on $\mathrm{Fe}$ isotopic fractionations commonly found in natural environments. The isotopically light $\delta^{56} \mathrm{Fe}$ of labile particulate $\mathrm{Fe}$, even when calculations indicate that $\mathrm{f}_{\text {labile }}$ is close to 1 , 
suggests some sort of methodological artifact. A possible cause of this discrepancy is non-homogenous loading of particles on the filters, which would lead to anomalously high values of $\mathrm{f}_{\text {labile }}$ (because the concentration of labile and total Fe were measured on different sections of the filter) even if both $\delta^{56} \mathrm{Fe}_{\text {labile }}$ and $\delta^{56} \mathrm{Fe}_{\text {total }}$ were representative of the true values. However, variability in filter loading has been estimated at close to $3 \%$ for the filtration procedures employed here (Ohnemus et al., this issue). Alternatively, the analytical uncertainties for $\delta^{56} \mathrm{Fe}_{\text {total }}, \delta^{56} \mathrm{Fe}_{\text {labile, }}\left[\mathrm{Fe}_{\text {total }}\right]$ or [ $\left.\mathrm{Fe}_{\text {labile }}\right]$ may have been underestimated.

Thirdly, we explored whether there could be analytical complications in our measurement of $\delta^{56} \mathrm{Fe}_{\text {labile }}$ due to the high concentration of organics in the leach and the large corrections for blank Fe, which must be made. However, there is little relationship between $\delta^{56} \mathrm{Fe}_{\text {labile }}$ and $f_{\text {blank }}\left(\mathrm{R}^{2}=0.17\right)$, suggesting that this was not the case in this study (Section 3.1, Fig. 5B). A lack of any systematic relationship between labile particulate $\delta^{56} \mathrm{Fe}$ and $\mathrm{F}_{\text {blank }}$ is consistent with a blank correction that is is accurate over a wide range of sample concentrations, though it is possible that subtle systematic error could be masked by variability in sample and blank $\delta^{56} \mathrm{Fe}$. Further, samples were processed with two different leach solutions containing very different quantities of $\mathrm{Fe}$ and blank $\delta^{56} \mathrm{Fe}$ (25.0 $\mathrm{ng} \mathrm{g}^{-1} \mathrm{Fe}, \delta^{56} \mathrm{Fe}=-3.62 \%$ for the first leach, and $80.0 \mathrm{ng} \mathrm{g}^{-1} \mathrm{Fe}, \delta^{56} \mathrm{Fe}=-0.37$ for the second leach). However, samples processed with the first leach (stations USGT 1110, 11-16, and 10-9) had similar [ $\left.\mathrm{Fe}_{\text {labile }}\right]$ and $\delta^{56} \mathrm{Fe}_{\text {labile }}$ compared to adjacent stations at similar depths processed with the second leach, with the exception of individual samples which we believe are strongly influenced by hydrothermal input (USGT11-16 below $3000 \mathrm{~m}$ ) and sedimentary reductive Fe input (USGT10-9 below $1000 \mathrm{~m}$ ).

A final analytical concern was the possibility for a kinetic isotope effect during leaching of particles with the oxalate-EDTA solution, which would be expected to cause the preferential release of lighter $\mathrm{Fe}$ isotopes from particles. At room temperature, $\mathrm{Fe}$ atoms attain equilibrium with the surface of nano-particulate ferrihydrite within about 11 days (Poulson et al., 2005). Fe is released from strong organic siderophores such as DFB on a similar timescale at $\mathrm{pH} \sim 8\left(t_{1 / 2}=220 \mathrm{~h}\right)$, though in the presence of competing ligands 
such as oxalate and EDTA this process will be much faster (Raymond et al., 1984). Using the rule of thumb that chemical reaction rates approximately double for every $10^{\circ} \mathrm{C}$ increase in temperature suggests that even these kinetically slow reactions will have reached equilibrium by the end of the two-hour leaching period at $90^{\circ} \mathrm{C}$. This assumption appears to be supported by the results of leaching Cariaco samples, which showed a maximum $0.1 \%$ kinetic isotope effect during leaching (Fig. 2, Section 3.1).

Considering both our experimental results from the Cariaco Basin sediment trap samples and our analysis of North Atlantic suspended particulate samples, we conclude that the evidence supports use of a pH 8 oxalate-EDTA leach to access a presumably biogeochemically relevant pool of exchangeable labile $\delta^{56} \mathrm{Fe}$. Some uncertainties remain about possible analytical artifacts associated with this technique, because natural marine particles are a complex mixture of phases and this leach cannot realistically be tested on every possible end-member phase and combination of phases. We therefore discuss our North Atlantic 'ligand-leachable' labile $\delta^{56} \mathrm{Fe}$ values under the assumption that they are accurate, but we recognize that additional work must be done to better understand how this leach interacts with natural marine particles.

\subsection{Total particle $\left[\mathrm{Fe}_{\text {total }}\right]$ and $\delta^{56} \mathrm{Fe}_{\text {total }}$}

Among North Atlantic samples analyzed for this study, total suspended particulate Fe concentrations ( $\left[\mathrm{Fe}_{\text {total }}\right]$ varied over five orders of magnitude, from 0.08 to $938 \mathrm{nmol} \mathrm{L}{ }^{-1}$ (Figs. 6 and 7). Much of this variability is driven by a small number of high concentration samples, with only $10 \%$ of samples having $\left[\mathrm{Fe}_{\text {total }}\right]$ greater than $4 \mathrm{nmol} \mathrm{L}{ }^{-1}$. Samples with the highest $\left[\mathrm{Fe}_{\text {total }}\right]$ include those from within the nepheloid layer near both the eastern and western margins (stations USGT10-9, USGT11-4, USGT11-6, and USGT11-8), and those from within the TAG hydrothermal plume (USGT11-16; 3000 to $3600 \mathrm{~m}$ ).

Total particulate $\delta^{56} \mathrm{Fe}$ within much of the ocean is very similar to that of average bulk crustal material (Figs. 6 and 7). The median $\delta^{56} \mathrm{Fe}_{\text {total }}$ was $+0.08 \%$, and the mean $\delta^{56} \mathrm{Fe}_{\text {total }}$ was $+0.08 \pm 0.09 \%$ ( 1 S.D.). These values are analytically indistinguishable within error to an average $\delta^{56} \mathrm{Fe}$ for many terrestrial end-members, including igneous rocks $(+0.09$; 
Beard et al., 2003), desert dusts from around the world (+0.08 $\pm 0.04 \%$; Waeles et al., 2007), total marine aerosols (+0.04 $\pm 0.09 \%$; Waeles et al., 2007), and average oxic seafloor sediment $\left(+0.13 \pm 0.04 \%\right.$; Beard et al., 2003). As was observed with $\left[\mathrm{Fe}_{\text {total }}\right]$, the samples with $\delta^{56} \mathrm{Fe}$ values furthest from the mean are those from unique, elevated particulate iron marine environments within the North Atlantic section. Two samples from within the nepheloid layer on the Mauritanian margin (USGT10-9; 8 and $26 \mathrm{nmol} \mathrm{L}^{-}$

$\left.{ }^{1}\left[\mathrm{Fe}_{\text {total }}\right]\right)$, where reducing sediments are thought to be a source of dissolved $\mathrm{Fe}(\mathrm{II})$ (Kuester-Heins et al., 2010), have a $\delta^{56} \mathrm{Fe}$ of $-0.28 \pm 0.03 \%$ and $-0.08 \pm 0.04 \%$, respectively (2 S.E.). Two samples from within the TAG-hydrothermal plume within the mid-Atlantic Ridge valley $\left(44.8^{\circ} \mathrm{W} 26.1^{\circ} \mathrm{N}\right)$ also have low $\delta^{56} \mathrm{Fe}$, of $-0.10 \pm 0.03 \%$ and $0.11 \pm 0.04 \%$ o (2 S.E.).

\subsection{Labile particle [Fe $\left.\mathrm{Fe}_{\text {labile] }}\right]$ and $\delta^{56} \mathrm{Fe}_{\text {labile }}$}

Concentrations of ligand-leachable particulate Fe in the North Atlantic, hereafter described as labile particulate $\mathrm{Fe}$, also vary greatly from our detection limit $\left(0.02 \mathrm{nmol} \mathrm{\textrm {L } ^ { - }}\right.$ ${ }^{1}$ ) up to $59.5 \mathrm{nmol} \mathrm{L}^{-1}$ (Figs. 6 and 7). Highest concentrations of $\mathrm{Fe}_{\text {labile were found in a }}$ small number of elevated suspended particulate Fe samples within benthic nepheloid layers near both continental margins and within the TAG hydrothermal plume. $90 \%$ of samples had $\mathrm{Fe}_{\text {labile }}$ concentrations below $1 \mathrm{nmol} \mathrm{L}{ }^{-1}$. 
Labile Fe stable isotope ratios $\left(\delta^{56} \mathrm{Fe}_{\text {labile }}\right)$ were more heterogeneous $(-1.21 \%$ to $+0.37 \%$ o $)$ than $\delta^{56} \mathrm{Fe}_{\text {total }}\left(-0.28 \%\right.$ o to $+0.34 \%$ ). Median $\delta^{56} \mathrm{Fe}_{\text {labile }}$ was $-0.27 \%$, and the mean $\delta^{56} \mathrm{Fe}_{\text {labile }}$ was $-0.30 \pm 0.17 \%$ ( $1 \sigma$ S.D.). The lowest $\delta^{56} \mathrm{Fe}_{\text {labile values were measured at }}$ station USGT10-9, just above the reducing sediments below the Mauritanian upwelling region (Kuester-Heins et al., 2010). We also observe lower mean $\delta^{56} \mathrm{Fe}_{\text {labile }}$ below $1000 \mathrm{~m}$ in the western basin, compared to samples in the deep central basin and eastern basin, and compared to samples from above $1000 \mathrm{~m}$. Excluding all samples above $1000 \mathrm{~m}$ and samples from stations USGT10-9 and USGT10-10 which may be influenced by Fe input from margin sediments, we calculate an overall deep-ocean mean $\delta^{56} \mathrm{Fe}_{\text {labile }}$ for the three western basin stations as $-0.47 \pm 0.09 \%$ ( $1 \sigma$ S.D.), while the deep-ocean mean $\delta^{56} \mathrm{Fe}$ for the six stations in the central and eastern basin is $-0.25 \pm 0.09 \%$ ( $1 \sigma$ S.D.).

\section{DisCUSSION}

Particulate Fe concentrations and $\delta^{56} \mathrm{Fe}$ are found to vary significantly throughout the North Atlantic U.S. GEOTRACES transect, with key differences between the total and labile phases. Here we discuss the overall distribution of particulate $[\mathrm{Fe}]$ and $\delta^{56} \mathrm{Fe}$ throughout the North Atlantic, as well as provide a more focused discussion of particulate Fe isotope biogeochemistry in nepheloid layers above reducing and non-reducing sediments, and near the TAG hydrothermal vents.

\subsection{Basin-wide distribution of total and labile Fe isotopes}

\subsubsection{Particulate Fe concentrations}

Labile and total particulate [Fe] have broadly similar distributions along the transect, though the median total particulate concentration $\left[\mathrm{Fe}_{\text {total }}\right]\left(1.09 \mathrm{nmol} \mathrm{L}^{-1}\right)$ is three times greater than the median labile concentration $\left[\mathrm{Fe}_{\text {labile }}\right]\left(0.35 \mathrm{nmol} \mathrm{L}^{-1}\right)$. The fraction labile $\left(f_{\text {labile }}=\mathrm{Fe}_{\text {labile }} / \mathrm{Fe}_{\text {total }}\right)$ highlights key differences in these concentration distributions and is shown in Fig. 4. Notably, both labile and total Fe concentrations are enriched by $>2$ orders of magnitude in the TAG hydrothermal plume at station USGT11-16 and in near- 
bottom nepheloid layers compared to the mid-ocean water column (Figs. 6 and 7). Total particulate Fe shows a noticeable depletion within the fluorescence maximum, while the depletion in [ $\left.\mathrm{Fe}_{\text {labile }}\right]$ is less pronounced, leading to an increase in $f_{\text {labile }}$ associated with fluorescence maxima across the transect (Fig. 3). This relative increase in flabile may be due to scavenging of dissolved $\mathrm{Fe}$ onto suspended particles, depletion in lithogenic particulate $\mathrm{Fe}$, increases in biogenic particulate $\mathrm{Fe}$, or various combinations of these factors.

\subsubsection{Particulate $\delta^{56} \mathrm{Fe}$}

Throughout the North Atlantic, $\delta^{56} \mathrm{Fe}_{\text {total }}$ is analytically indistinguishable from $\delta^{56} \mathrm{Fe}$ of many lithogenic Fe sources to the ocean (Section 3.3), suggesting a dominant lithogenic source contribution. For all samples measured, the mean and median $\delta^{56} \mathrm{Fe}_{\text {labile }}$ are both lower than $\delta^{56} \mathrm{Fe}_{\text {total }}$ by $0.4 \%$. By comparing the difference in labile and total $\delta^{56} \mathrm{Fe}$ $\left(\Delta \delta^{56} \mathrm{Fe}_{\text {labile-total }}\right)$ and $f_{\text {labile, }}$, and assuming that total $\mathrm{Fe}$ is composed of a combination of labile and refractory phases, we determine that the entire North Atlantic dataset is best fit by assuming an average $\Delta \delta^{56} \mathrm{Fe}_{\text {labile-refractory }}=-0.49 \%$ (Fig. 5), though there is a great deal of scatter around this relationship $\left(\mathrm{R}^{2}=0.28\right)$, reflecting both analytical variability and real differences in $\delta^{56} \mathrm{Fe}_{\text {labile }}$ in different parts of the North Atlantic. While ligandleachable $\delta^{56} \mathrm{Fe}$ is generally isotopically light compared to continental material throughout the North Atlantic, most North Atlantic seawater dissolved $\delta^{56} \mathrm{Fe}$ is isotopically heavier than continental material $(+0.3$ to $+0.7 \%$ ) (Boyle et al., 2012; Conway and John, 2014; John and Adkins, 2012). John and Adkins observed that dissolved $\delta^{56} \mathrm{Fe}$ was relatively homogenous throughout the water column at Bermuda, which they hypothesized might be due to an isotopic equilibrium between the dissolved and labile particulate $\mathrm{Fe}$ reservoirs. The low $\delta^{56} \mathrm{Fe}_{\text {labile }}$ observed for ligand-leachable $\mathrm{Fe}$ on the surface of particles might be due to transfer of isotopically heavy Fe from particles to the dissolved phase. However, more work is required to confirm this hypothesis, as it is necessary to better constrain the rates at which $\mathrm{Fe}$ is transferred between the dissolved and particulate phases, and to better understand whether the ligand-leachable particulate 
Fe studied here is truly representative of the natural marine particulate phases in equilibrium with dissolved seawater Fe.

Average $\delta^{56} \mathrm{Fe}_{\text {labile }}$ in the western basin below $1000 \mathrm{~m}$ is about $0.2 \%$ lighter than in the central and eastern basin (Fig. 6, Section 3.4). We attribute this different to higher proportion of suspended particulate Fe coming from resuspended seafloor sediments in the western basin, and a higher proportion of particulate Fe contributed by Saharan dust in the central and eastern basin. This interpretation is supported by several other datasets including elevated Fe:Ti and lower total Ti:Al in the suspended particulate phase, and particulate Fe inventories in the western basin between Woods Hole and Bermuda which are too large to be supported by Saharan dust deposition (Ohnemus and Lam, this issue), and a unique dissolved $\delta^{56} \mathrm{Fe}$ signature attributed to non-reductive dissolution observed in the western basin (Conway and John, 2014). The spatial distribution of low $\delta^{56} \mathrm{Fe}_{\text {labile, }}$ high Fe:Ti, and low Ti:Al in the North Atlantic are all very similar, appearing only below $1000 \mathrm{~m}$ in the western basin to station USGT11-10 $\left(64.2^{\circ} \mathrm{W}\right)$ and below $5000 \mathrm{~m}$ at station USGT11-12 $\left(56.8^{\circ} \mathrm{W}\right)$. The underlying reason for the observed difference in $\delta^{56} \mathrm{Fe}_{\text {labile }}$ between western basin and central/eastern basin particles is unknown. It could be attributed either to mineralogical differences between African-sourced minerals in dust and North American-sourced minerals in the western margin sediments, or it could be attributed to differences in particle surface chemistry related to particle aging on the seafloor.

\subsection{Nepheloid layer particles}

Both $\mathrm{Fe}_{\text {total }}$ and $\mathrm{Fe}_{\text {labile }}$ concentrations are elevated near the sediments at stations along both the eastern and western margins of the North Atlantic. However, the $\delta^{56} \mathrm{Fe}$ of nepheloid-layer particles along these two margins is quite different. Along the eastern margin underneath the Mauritanian upwelling region at station USGT10-09, particulate

$\delta^{56} \mathrm{Fe}$ is as low as $-1.21 \%$ in the labile phase and $-0.29 \%$ o for total $\mathrm{Fe}$. We interpret this as the result of isotopically light Fe(II) release into reducing porewaters within the sediments (Kuester-Heins et al., 2010), and the subsequent precipitation of this Fe upon 
interaction with oxic seawater. Several studies have shown that dissolved $\delta^{56} \mathrm{Fe}$ in reducing pore waters is isotopically light compared with bulk sediments, with values typically about $-3 \%$ near the sediment water interface (Severmann et al., 2010, 2006) reflecting the equilibrium isotopic fractionation between $\mathrm{Fe}(\mathrm{II})$ and $\mathrm{Fe}(\mathrm{III})$ (Welch et al., 2003). The fact that labile particulate Fe near these sediments is isotopically lighter than total particulate Fe suggests precipitation of isotopically light Fe oxyhydroxides on the surface of or in association with sedimentary material which has a heavier, crustal isotope composition (e.g. silicates). Our data do not allow us to differentiate between precipitation onto suspended particles within the water column and precipitation in sediments followed by resuspension of particles. However, we note that sedimentary Fe in the solid phase, even in sediments with reducing pore-waters, is typically close to crustal values (Homoky et al., 2013) and so for there to be a sufficient quantity of precipitated light Fe to change the total particulate $\delta^{56} \mathrm{Fe}$ values to $<0 \%$ is perhaps indicative of processes happening above the sediment-water interface. Assuming that the labile particulate $\mathrm{Fe}$ is a mixture between lithogenic Fe with a $\delta^{56} \mathrm{Fe}$ of $+0.13 \%$ o (Beard et al., 2003) and Fe released from sediments as Fe(II) and authigenically precipitated onto particles in the water column with a $\delta^{56} \mathrm{Fe}$ of $-1.82 \%$ (John et al., 2012), isotope mass balance suggests that up to $69 \%$ of labile particulate Fe may be precipitated within the water column. The hypothesis that suspended particulate Fe is a mixture between resuspended sediments and Fe precipitated within the water column is further supported by the fact that the lowest values of $\delta^{56} \mathrm{Fe}_{\text {total }}$ and $\delta^{56} \mathrm{Fe}_{\text {labile }}$ both occur not in the deepest sample at USGT10-09, but in the second-deepest sample, suggesting a mixture of sediment resuspension and authigenic Fe oxyhydroxide precipitation at both depths, with a larger contribution from resuspended sediments in the bottom sample and a larger relative contribution from water column precipitation in the second-deepest sample.

At the station closest to the eastern margin (USGT10-09), concentration profiles of total and labile particulate Fe possess two distinct subsurface maxima: one above $800 \mathrm{~m}$ centered at $400 \mathrm{~m}$, and a deeper one centered at $1700 \mathrm{~m}$. There is a notable isotopic difference in mean $\delta^{56} \mathrm{Fe}_{\text {labile }}$ from the surface down to $800 \mathrm{~m}(-0.36 \pm 0.05 \%$; $1 \sigma$ S.D.) compared to values from $950 \mathrm{~m}$ and below $(-0.80 \pm 0.06 \%$ ( $1 \sigma$ S.D. $)$, excluding the two 
deepest samples taken within the nepheloid layer. The shallower particulate Fe maximum at $400 \mathrm{~m}$ coincides with the minimum in oxygen concentration $\left(40 \mu \mathrm{M} \mathrm{O}_{2}\right)$, suggesting that this feature is related to remineralization. Indeed, simple one-dimensional modeling of particle dynamics can generate a similar shallow lithogenic metal maximum by considering only dust deposition at the surface followed by particle aggregation, sinking, and disaggregation of suspended dust particles that accumulate at the oxygen minimum/remineralization maximum (Ohnemus and Lam, this issue). These dynamics can also generate multiple subsurface maxima if dust inputs vary in time, though our observation of isotopically light $\delta^{56} \mathrm{Fe}_{\text {labile }}$ below $800 \mathrm{~m}$ suggests an additional non-crustal input for the second, deeper particulate maximum, which could be lateral advection of particles containing isotopically light Fe from reducing margin sediments.

High Fe concentrations are also observed in the nepheloid layers on the western margin at stations USGT11-04, USGT11-08, and USGT11-10. Unlike the eastern margin nepheloid layer at USGT10-09 that exhibited elevated Fe:Ti in total digests, western margin nepheloid layers had crustal Fe:Ti (Ohnemus and Lam, this issue). This suggests an absence of reductively mobilized iron in near-bottom particulates along the western margin. Nepheloid layer samples from stations USGT11-04 and USGT11-08 were not tested for ligand-leachable [Fe] and $\delta^{56} \mathrm{Fe}$. However, within a strong nephloid layer observed at station USGT11-10, $\delta^{56} \mathrm{Fe}$ was not significantly lighter than for samples taken above the nephloid layer. Additionally, there was no evidence of isotopically light Fe from reducing sediments within the total particulate $\delta^{56} \mathrm{Fe}$ from any of the nephloid layers in the western basin. This is consistent with the dominance of $\mathrm{O}_{2}$ as the main electron acceptor for organic matter oxidation on the western margin (Martin and Sayles, 2004). Just as dissolved $\delta^{56} \mathrm{Fe}$ has been used to distinguish between reductive and nonreductive sedimentary sources of Fe to the water column (Conway and John, 2014; Homoky et al., 2013, 2009; Radic et al., 2011), our measurements of particle $\delta^{56} \mathrm{Fe}$ appeared to be a good tool for distinguishing between $\mathrm{Fe}$ in the particle phase being sourced from reductive and non-reductive sedimentary environments.

\subsection{Hydrothermal vent particles}


Labile and total $\mathrm{Fe}$ have similar [Fe] and $\delta^{56} \mathrm{Fe}$ within the TAG hydrothermal plume (>3000 $\mathrm{m}$ at station USGT11-16;26 $\left.\mathrm{N}, 45^{\circ} \mathrm{W}\right)$ (Fig. 8). This suggests that plume particles are completely dissolved by the oxalate-EDTA leach. The exception to this relationship is the deepest sample, taken at $3600 \mathrm{~m}$, just $95 \mathrm{~m}$ above bottom depth. $\mathrm{f}_{\text {labile }}$ was 0.68 in this deepest sample, compared to $f_{\text {labile }}$ of 1.01 to 1.28 for all other samples in the plume. Also, while $\delta^{56} \mathrm{Fe}_{\text {labile }}$ and $\delta^{56} \mathrm{Fe}_{\text {total }}$ were analytically indistinguishable within error for most of the plume, the labile phase was isotopically lighter than total Fe in the deepest sample. The labile phase $\delta^{56} \mathrm{Fe}$ is the same as that of pure TAG hydrothermal fluids (-0.32+/- 0.04; Severmann et al., 2004), while total $\delta^{56}$ Fe was $-0.10 \%$, suggesting that this sample is a mixture of isotopically lighter hydrothermal Fe with an isotopically heavier refractory phase such as silicate sediments or the background dust particulate load.

We also observe that within the neutrally-buoyant hydrothermal plume, elevated $[\mathrm{Fe}]$ is correlated with more positive $\delta^{56} \mathrm{Fe}$ (Fig. 8). This matches the observations of Severmann et al. (2004) who measured eighteen particle samples from nine different locations both within the buoyant plume just above the vent and in the neutrally-buoyant plume dispersing laterally away from the vent. Severmann et al. observed the highest $\delta^{56} \mathrm{Fe}$ $(+1.05 \%)$ in samples nearest to the vent (where we expect Fe concentrations to be highest) and observed a decrease in $\delta^{56} \mathrm{Fe}$ away from the vent. The lowest particulate $\delta^{56} \mathrm{Fe}$ values observed by Severmann were $-0.3 \%$, which matched their average $\delta^{56} \mathrm{Fe}$ for pure TAG hydrothermal vent fluids of $-0.32 \pm 0.04 \%$. The lowest $\delta^{56} \mathrm{Fe}$ we measured in the hydrothermal plume was $-0.29 \%$ for the labile phase in the deepest sample, also within error of the $\delta^{56} \mathrm{Fe}$ for TAG pure hydrothermal fluids. Severmann et al. interpreted these data as reflecting the preferential precipitation of isotopically heavy $\mathrm{Fe}(\mathrm{III})$ oxyhydroxides during early stages of plume evolution, followed by quantitative precipitation of Fe onto particles during later stages of plume evolution, so that particle $\delta^{56} \mathrm{Fe}$ further away from the vent matches source (vent fluid) $\delta^{56} \mathrm{Fe}$; our data can be interpreted in the same way. 
Away from the TAG site, the highest values of $f_{\text {labile }}$ in the deep ocean are found at the approximate height of the neutrally buoyant hydrothermal plume (2000 - $4000 \mathrm{~m})$, with $f_{\text {labile }}$ values $>0.6$ as far west as station USGT11-12 $\left(57^{\circ} \mathrm{W}\right)$. This is consistent with elevated Fe:Ti ratios in the total particle digests that are also observed at the same depths and stations (Ohnemus and Lam, this issue). The lowest values of $\delta^{56} \mathrm{Fe}_{\text {total }}$ were observed in this same depth range at stations USGT11-12 and USGT11-14 $\left(50^{\circ} \mathrm{W} ; 3000\right.$ $\mathrm{m} ;-0.06 \pm 0.05 \%$ and $-0.10 \pm 0.04 \%$, respectively). This data suggests possible far-field dispersal of particles of hydrothermal origin throughout the deep western basin.

\section{Conclusions}

Measurements of labile and total Fe stable isotope ratios are a valuable tool for understanding the biogeochemical cycling of Fe in the North Atlantic. Our measurements of $\delta^{56} \mathrm{Fe}_{\text {total }}$ show that most $0.8-50 \mu \mathrm{m}$ suspended particles in the North Atlantic have an analytically indistinguishable $\delta^{56} \mathrm{Fe}$ compared to continental material, reflecting the important contribution of dust and resuspended seafloor sediments to the total particle load. In contrast, our measurements of $\delta^{56} \mathrm{Fe}_{\text {labile }}$ indicate that most suspended particles in the North Atlantic contain an isotopically light ligand-leachable labile phase, although uncertainties about the application of an oxalate-EDTA leach to Fe isotope studies remain. In the TAG hydrothermal plume itself we find that most Fe is contained within the labile phase, and our data matches that of previous studies that observed particles as isotopically heavier close to the hydrothermal vents and growing isotopically lighter with distance away from the vents. In nepheloid layers along the eastern margin of the North Atlantic, above reducing sediments, we observe the light isotopic signature of reduced porewater $\mathrm{Fe}$ (II) which has precipitated onto the particulate phase. In contrast, along the western margin, high Fe concentrations in a nepheloid layer near Bermuda are not associated with an isotopically light $\delta^{56} \mathrm{Fe}$ signature, suggesting the dominance of resuspended terrigenous material. Future methodological studies may help us clarify exactly how the oxalate-EDTA leach interacts with particles so that we can better understand how to interpret ligand-leachable $\delta^{56} \mathrm{Fe}$ data, and may shed light on the 
processes by which Fe isotopes are exchanged between the dissolved and particulate phases in the ocean. 


\section{Acknowledgements}

The authors would like to thank the captain and crew of the $R / V$ Knorr, the US

GEOTRACES pumping team for sampling along the US GEOTRACES A03 transect, Bob Thunell for providing Cariaco Basin sediment trap material, and Angela Rosenberg, Florence Hartman, Beth Bair and Carl Frisby for technical assistance at USC. This work was supported by the University of South Carolina and National Science Foundation grants to S. John (OCE \#1131387) and P. Lam (OCE \#0963026). 


\section{References}

Beard, B.L., Johnson, C.M., Von Damm, K.L., Poulson, R.L., 2003. Iron isotope constraints on Fe cycling and mass balance in oxygenated Earth oceans. Geology 31, 629-632.

Bennett, S.A., Rouxel, O., Schmidt, K., Garbe-Schönberg, D., Statham, P.J., German, C.R., 2009. Iron isotope fractionation in a buoyant hydrothermal plume, $5^{\circ} \mathrm{S}$ MidAtlantic Ridge. Geochim. Cosmochim. Acta 73, 5619-5634.

Bennett, S.A., Rouxel, O., Schmidt, K., Garbe-Schönberg, D., Statham, P.J., German, C.R., Achterberg, E.P., Connelly, D.P., Statharn, P.J., Fones, G.R., Gernian, C.R., 2008. The distribution and stabilisation of dissolved Fe in deep-sea hydrothermal plumes. Earth Planet. Sci. Lett. 270, 157-167.

Berger, C.J.M., Lippiatt, S.M., Lawrence, M.G., Bruland, K.W., 2008. Application of a chemical leach technique for estimating labile particulate aluminum, iron, and manganese in the Columbia River plume and coastal waters off Oregon and Washington. J. Geophys. Res. 113, 16.

Boyle, E.A., John, S.G., Abouchami, W., Adkins, J.F., Echegoyen-Sanz, Y., Ellwood, M., Flegal, A.R., Fornace, K., Gallon, C., Galer, S., Gault-Ringold, M., Lacan, F., Radic, A., Rehkamper, M., Rouxel, O., Sohrin, Y., Stirling, C., Thompson, C., Vance, D., Xue, Z., Zhao, Y., 2012. GEOTRACES IC1 (BATS) contaminationprone trace element isotopes $\mathrm{Cd}, \mathrm{Fe}, \mathrm{Pb}, \mathrm{Zn}, \mathrm{Cu}$, and $\mathrm{Mo}$ intercalibration. Limnol. Oceanogr. 10, 653-665.

Conway, T.M., John, S.G., 2014. Quantification of dissolved iron sources to the North Atlantic Ocean. Nature 511, 212-215.

Conway, T.M., Rosenberg, A.D., Adkins, J.F., John, S.G., 2013. A new method for precise determination of iron, zinc and cadmium stable isotope ratios in seawater by double-spike mass spectrometry. Anal. Chim. Acta 793, 44-52.

Gelting, J., Breitbarth, E., Stolpe, B., Hassellöv, M., Ingri, J., 2010. Fractionation of iron species and iron isotopes in the Baltic Sea euphotic zone. Biogeosciences 7, 24892508.

Homoky, W.B., John, S.G., Conway, T.M., Mills, R. a, 2013. Distinct iron isotopic signatures and supply from marine sediment dissolution. Nat. Commun. 4, 2143.

Homoky, W.B., Severmann, S., Mills, R.A., Statham, P.J., Fones, G.R., 2009. Pore-fluid Fe isotopes reflect the extent of benthic Fe redox recycling: Evidence from continental shelf and deep-sea sediments. Geology 37, 751-754. 
John, S.G., 2012. Optimizing sample and spike concentrations for isotopic analysis by double-spike ICPMS. J. Anal. At. Spectrom. 27, 2123.

John, S.G., Adkins, J.F., 2012. The vertical distribution of iron stable isotopes in the North Atlantic near Bermuda. Global Biogeochem. Cycles 26, n/a-n/a.

John, S.G., Mendez, J., Moffett, J., Adkins, J.F., 2012. The flux of iron and iron isotopes from San Pedro Basin sediments. Geochim. Cosmochim. Acta 93, 14-29.

Kuester-Heins, K., de Lange, G.J., Zabel, M., 2010. Benthic phosphorus and iron budgets for three NW African slope sediments: a balance approach. Biogeosciences 7, 469480 .

Lacan, F., Radic, A., Jeandel, C., Poitrasson, F., Sarthou, G., Pradoux, C., Freydier, R., 2008. Measurement of the isotopic composition of dissolved iron in the open ocean. Geophys. Res. Lett. 35, -.

Lacan, F., Radic, A., Labatut, M., Jeandel, C., Poitrasson, F., Sarthou, G., Pradoux, C., Chmeleff, J., Freydier, R., 2010. High-precision determination of the isotopic composition of dissolved iron in iron depleted seawater by double-spike multicollector-ICPMS. Anal. Chem. 55, 7103-7111.

Martin, W.R., Sayles, F.L., 2004. Organic matter cycling in sediments of the continental margin in the northwest Atlantic Ocean. Deep. Res. Part I-Oceanographic Res. Pap. $51,457-489$.

Martinez, N., Murray, R., Thunell, R., Peterson, L., Mullerkarger, F., Astor, Y., Varela, R., 2007. Modern climate forcing of terrigenous deposition in the tropics (Cariaco Basin, Venezuela). Earth Planet. Sci. Lett. 264, 438-451.

Moore, J.K., Doney, S.C., Glover, D.M., Fung, I.Y., 2002. Iron cycling and nutrientlimitation patterns in surface waters of the World Ocean. Deep. Res. Part Ii-Topical Stud. Oceanogr. 49, 463-507.

Ohnemus, D.C., Lam, P.J., this issue. Cycling of Lithogenic Marine Particulates in the US GEOTRACES North Atlantic Zonal Transect. Deep Sea Res. Part II Top. Stud. Oceanogr.

Ohnemus, D.C., Sherrell, R.M., Lagerstöm, M., Morton, P.L., Twining, B.S., Rauschenberg, S.M., Auro, M.E., Lam, P.J., this issue. Piranha: a chemical method for dissolution of polyethersulfone filters and laboratory intercomparison of marine particulate digests. Limnol. Oceanogr.

Poulson, R.L., Johnson, C.M., Beard, B.L., 2005. Iron isotope exchange kinetics at the nanoparticulate ferrihydrite surface. Am. Mineral. 90, 758-763. 
Radic, A., Lacan, F., Murray, J.W., 2011. Iron isotopes in the seawater of the equatorial Pacific Ocean: New constraints for the oceanic iron cycle. Earth Planet. Sci. Lett. 306, 1-10.

Raymond, K.N., Muller, G., Matzanke, B.F., 1984. Complexation of iron by siderophores - a review of their solution and structural chemistry and biological function. Top. Curr. Chem. 123, 49-102.

Severmann, S., Johnson, C.M., Beard, B.L., German, C.R., Edmonds, H.N., Chiba, H., Green, D.R.H., 2004. The effect of plume processes on the Fe isotope composition of hydrothermally derived $\mathrm{Fe}$ in the deep ocean as inferred from the Rainbow vent site, Mid-Atlantic Ridge, $36^{\circ} 14^{\prime}$ N. Earth Planet. Sci. Lett. 225, 63-76.

Severmann, S., Johnson, C.M., Beard, B.L., McManus, J., 2006. The effect of early diagenesis on the Fe isotope compositions of porewaters and authigenic minerals in continental margin sediments. Geochim. Cosmochim. Acta 70, 2006-2022.

Severmann, S., McManus, J., Berelson, W.M., Hammond, D.E., 2010. The continental shelf benthic iron flux and its isotope composition. Geochim. Cosmochim. Acta 74, 3984-4004.

Siebert, C., Nagler, T.F., Kramers, J.D., 2001. Determination of molybdenum isotope fractionation by double-spike multicollector inductively coupled plasma mass spectrometry. Geochemistry Geophys. Geosystems 2, doi:10.1029/2000GC000124.

Staubwasser, M., Schoenberg, R., von Blanckenburg, F., Krüger, S., Pohl, C., 2013. Isotope fractionation between dissolved and suspended particulate $\mathrm{Fe}$ in the oxic and anoxic water column of the Baltic Sea. Biogeosciences 10, 233-245.

Tessier, A., Campbell, P.G.C., Bisson, M., 1979. Sequential extraction procedure for the speciation of particulate trace metals. Anal. Chem. 51, 844-851.

Tovar-Sanchez, A., Sañudo-Wilhelmy, S., Garcia-Vargas, M., Weaver, R.S., Popels, L.C., Hutchins, D.A., Sanudo-Wilhelmy, S.A., 2003. A trace metal clean reagent to remove surface-bound iron from marine phytoplankton. Mar. Chem. 82, 91-99.

Waeles, M., Baker, A.R., Jickells, T., Hoogewerff, J., 2007. Global dust teleconnections: aerosol iron solubility and stable isotope composition. Environ. Chem. 4, 233-237.

Welch, S.A., Beard, B.L., Johnson, C.M., Braterman, P.S., 2003. Kinetic and equilibrium Fe isotope fractionation between aqueous Fe(II) and Fe(III). Geochim. Cosmochim. Acta 67, 4231-4250. 


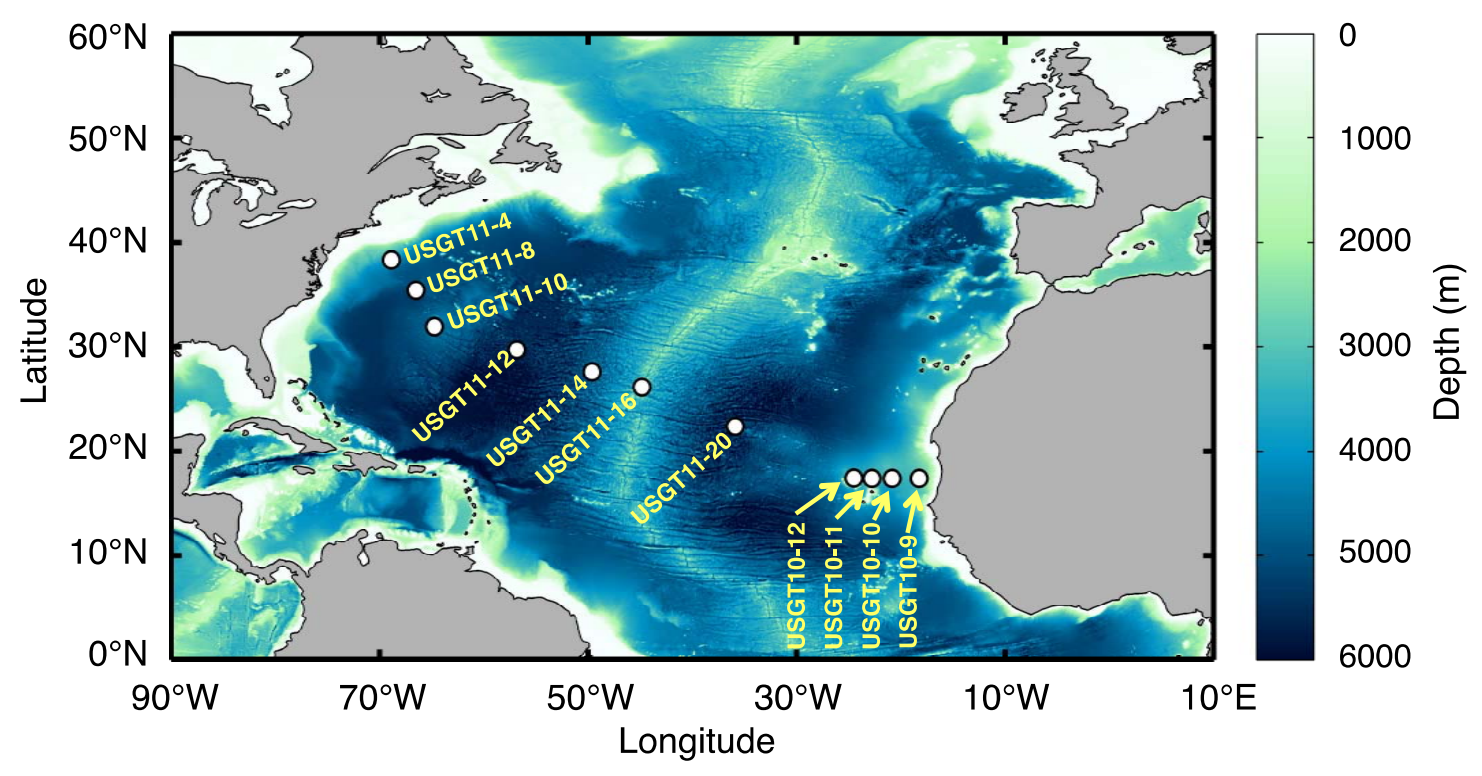

Figure 1. Stations along the US GEOTRACES A03 North Atlantic zonal transect (NAZT) from which samples were analyzed as part of this study for labile and total $\mathrm{Fe}$ concentrations and $\mathrm{Fe}$ isotope ratios $\left(\delta^{56} \mathrm{Fe}\right)$. 


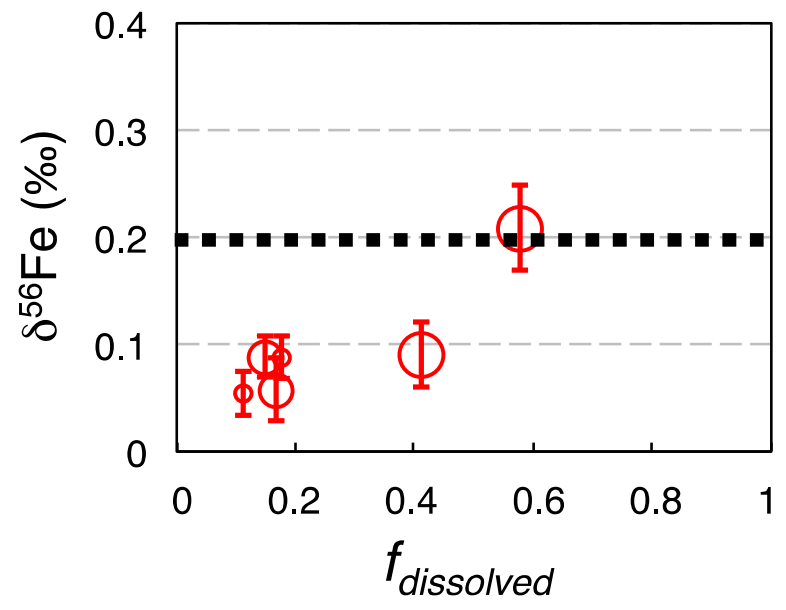

Figure 2. Leachate isotope ratio $\left(\delta^{56} \mathrm{Fe}\right)$ for an oxalate-EDTA leach of Cariaco Basin sediment trap samples, compared to the fraction of total particulate Fe that was dissolved in each experiment $\left(f_{\text {dissolved }}\right)$. Leaches were performed at $90^{\circ} \mathrm{C}$ for $10 \mathrm{~min}$. (small circles), $2 \mathrm{hr}$. (medium circles), or $24 \mathrm{~h}$ (largest circles). The $\delta^{56} \mathrm{Fe}$ of a total digestion of these particles with $\mathrm{HF}-\mathrm{HNO}_{3}$ is indicated by the dashed black line. 


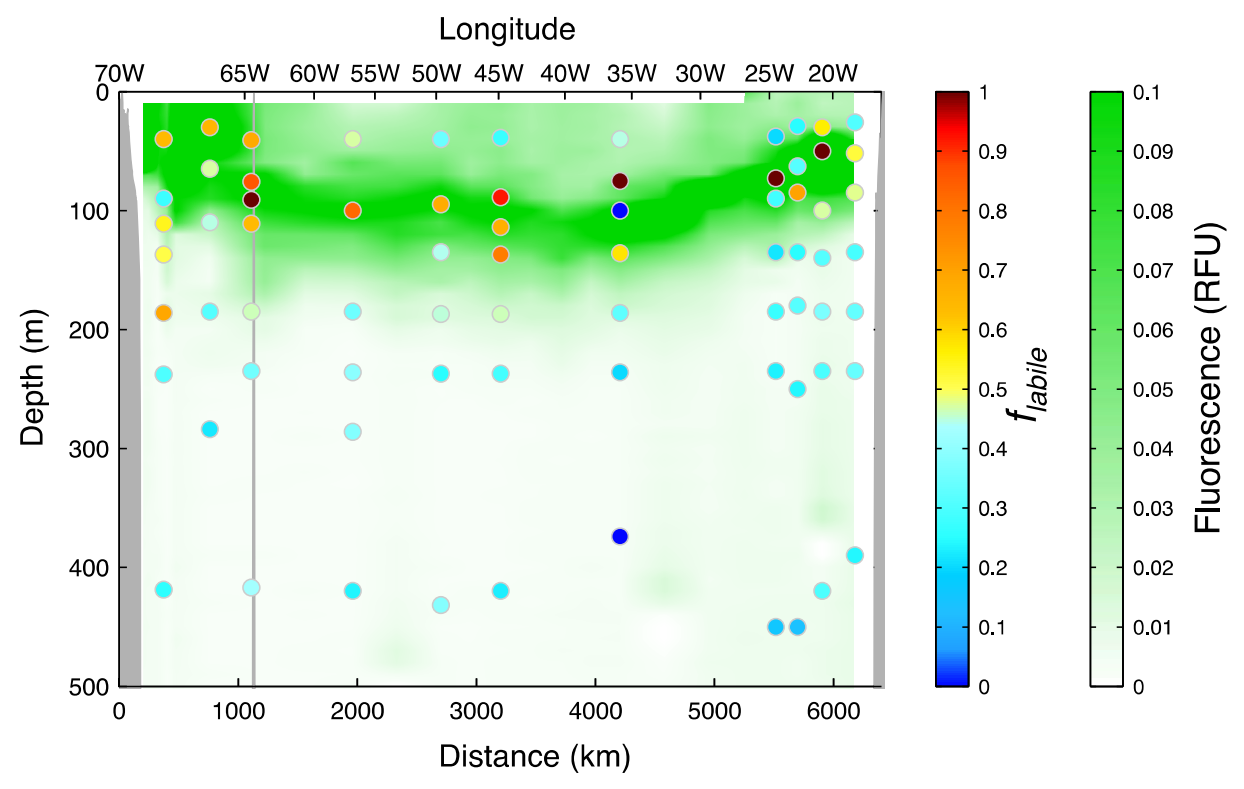

Figure 3. Fraction of total suspended particle Fe found in the labile phase $\left(f_{\text {labile }}\right)$ overlain on CTD fluorescence (relative fluorescence units) for the top $500 \mathrm{~m}$ of U.S.

GEOTRACES North Atlantic zonal transect, demonstrating high $f_{\text {labile }}$ within the maximum in fluorescence. 


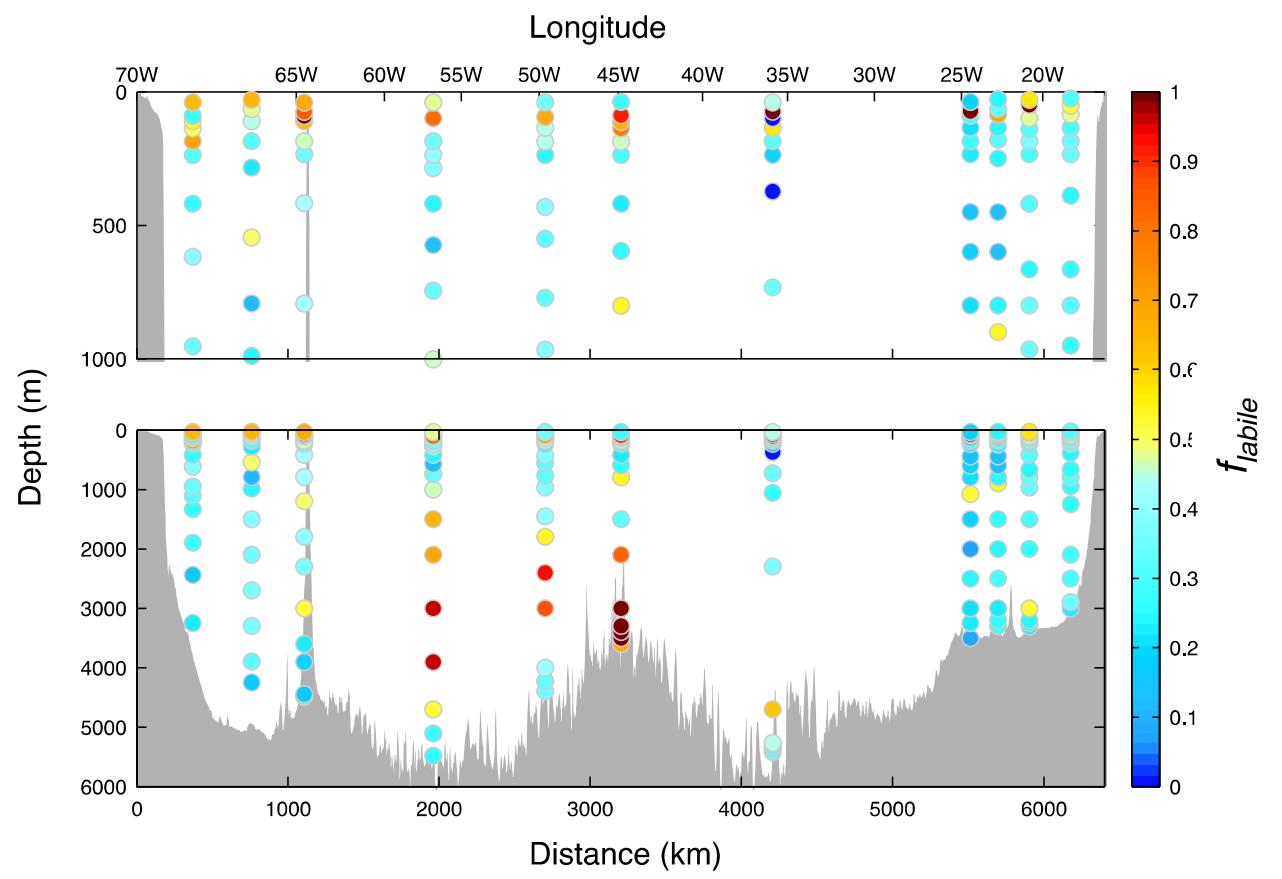

Figure 4. Fraction of total suspended particle Fe found in the labile phase $\left(f_{\text {labile }}\right)$ across the U.S. GEOTRACES North Atlantic zonal transect. 

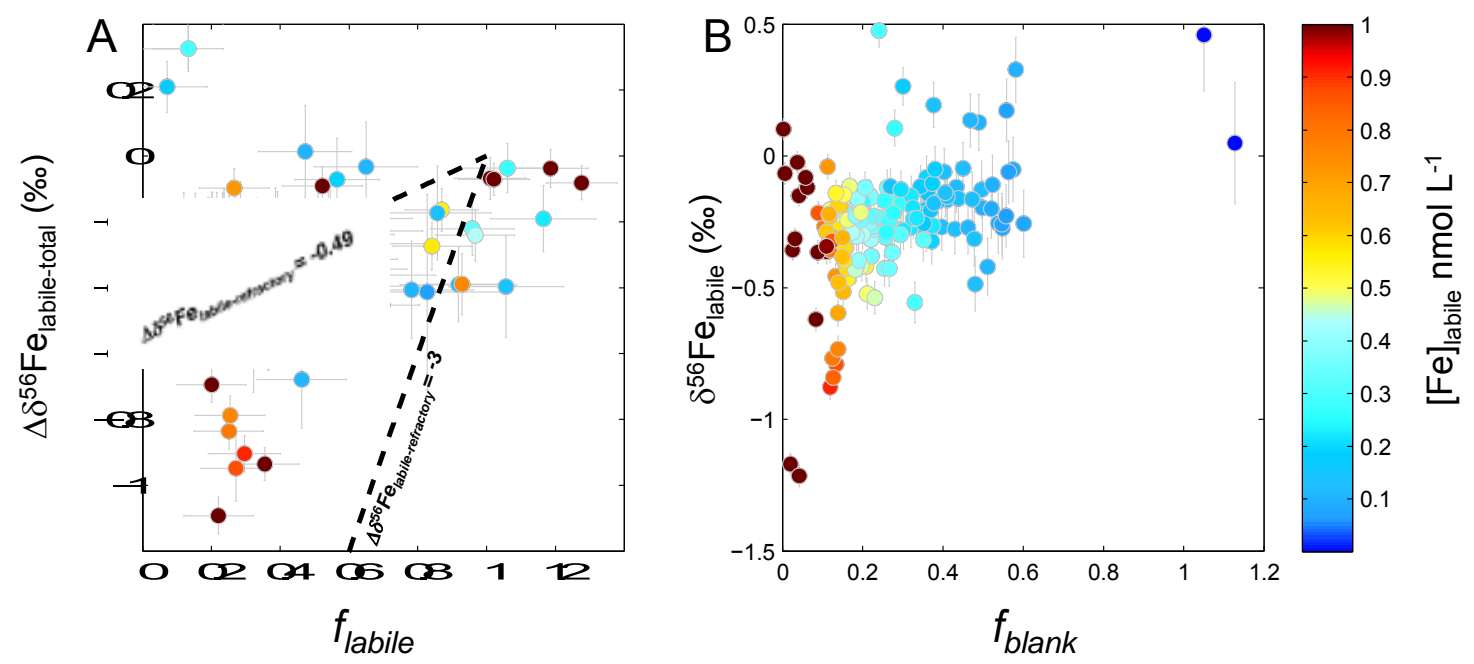

Figure 5. The relationship between suspended particulate Fe concentration [Fe] and $\mathrm{Fe}$ isotope ratio $\left(\delta^{56} \mathrm{Fe}\right)$ in the labile and total phases in samples from the $\mathrm{U}$. S. GEOTRACES North Atlantic zonal transect (NAZT). (A) The isotopic difference between labile and total $\delta^{56} \mathrm{Fe}\left(\Delta \delta^{56} \mathrm{Fe}_{\text {labile-total }}\right)$ should approach zero as the fraction labile $\left(f_{\text {labile }}\right)$ approaches 1 , along a line determined by the isotopic difference between labile and refractory phases $\left(\Delta \delta^{56} \mathrm{Fe}_{\text {refractory-total }}\right.$ (dashed black lines). The best fit for all data is for $\Delta \delta^{56} \mathrm{Fe}_{\text {labile-refractory }}=-0.49 \%$. Data for NAZT samples generally fall above a line for $\Delta \delta^{56} \mathrm{Fe}_{\text {labile-refractory }}=-3 \%$, especially when the concentration of labile particulate $\mathrm{Fe}$ ([$\left[\mathrm{Fe}_{\text {labile }}\right]$ ) is high (red colors). (B) The relationship between $\delta^{56} \mathrm{Fe}$ of the labile phase ( $\delta^{56} \mathrm{Fe}_{\text {labile }}$; after blank correction) and the fraction of the labile $\mathrm{Fe}$ that was contributed by the blank $\left(f_{\text {blank }}\right)$. 

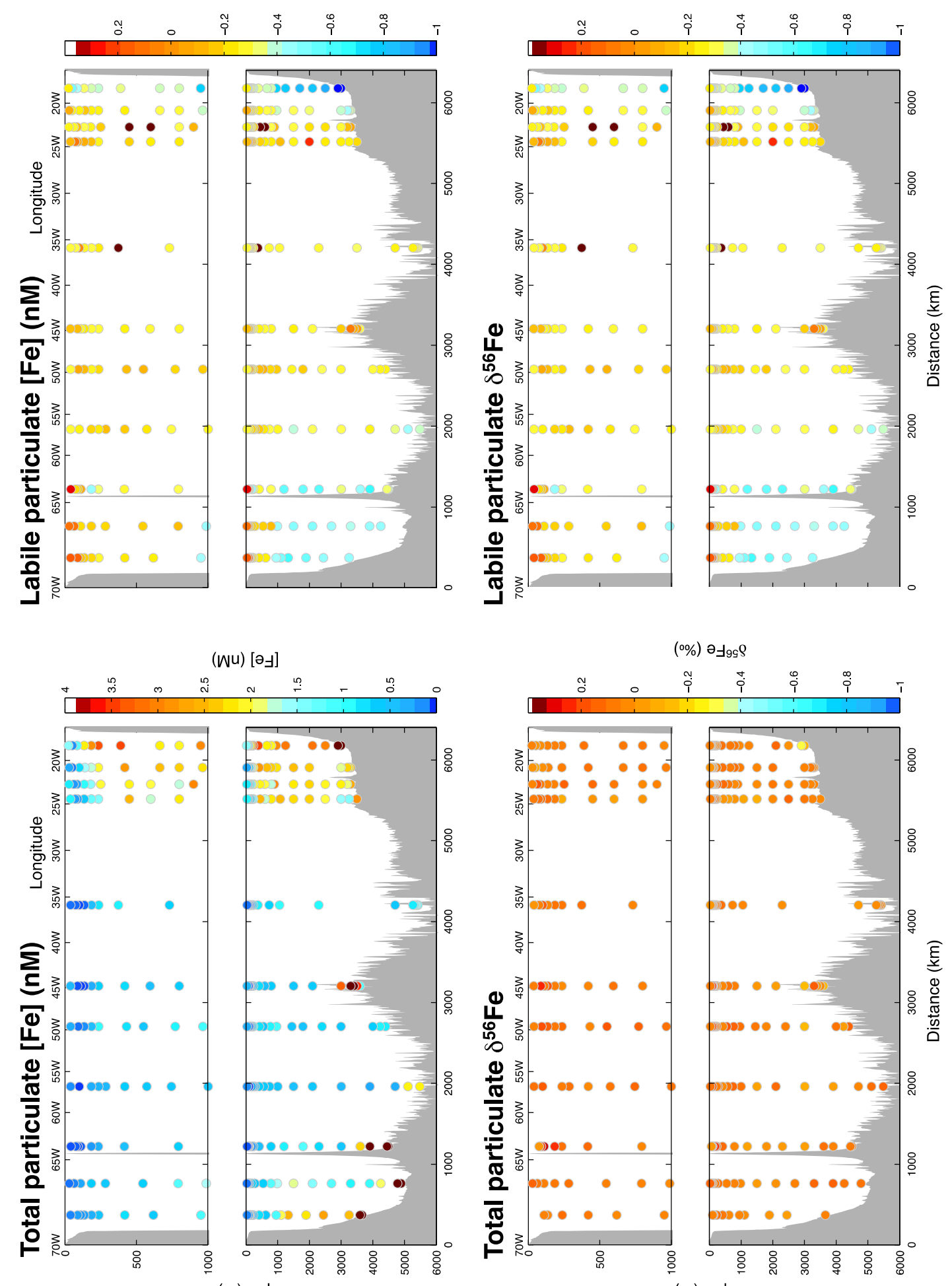

(w) पाdə⿳亠口冋

(w) प1də0

Figure 6. Total and labile suspended particle Fe concentration ([Fe]) and Fe isotope ratios $\left(\delta^{56} \mathrm{Fe}\right)$ in samples from stations along the US GEOTRACES North Atlantic zonal transect. 
Figure 7. Individual profiles of total and labile suspended particle Fe concentration ([Fe]) and $\mathrm{Fe}$ isotope ratio $\left(\delta^{56} \mathrm{Fe}\right)$ along the U. S. GEOTRACES North Atlantic zonal transect.
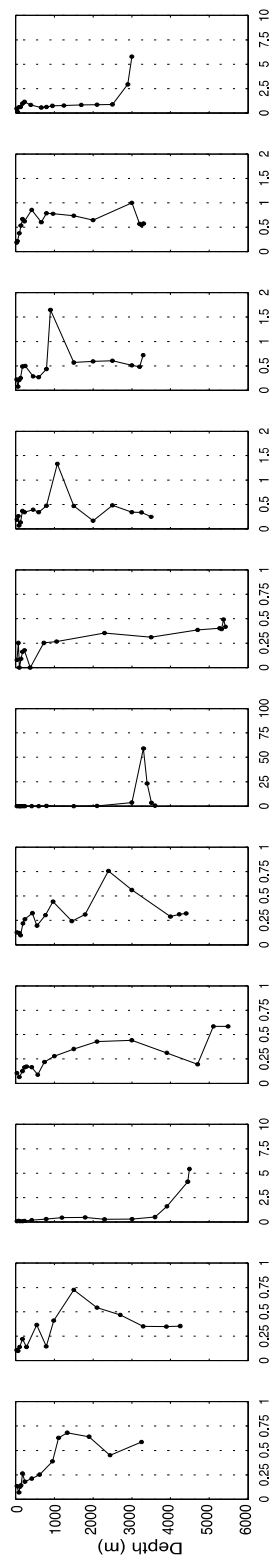

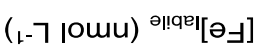
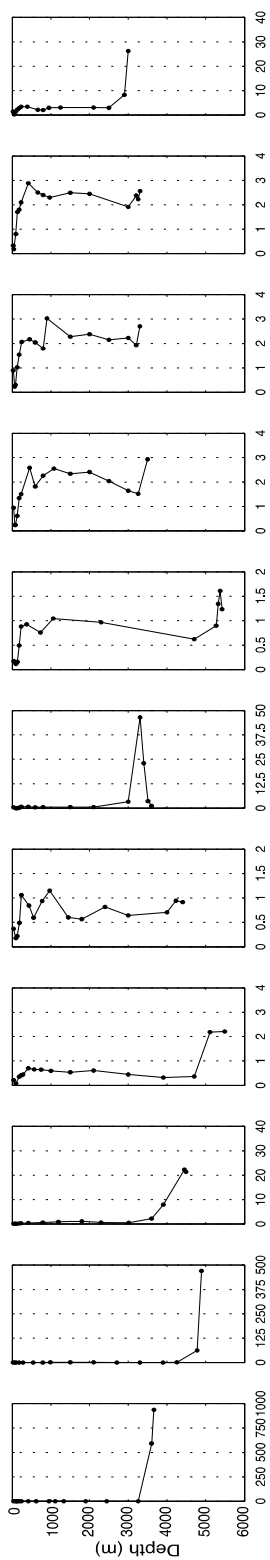

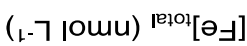
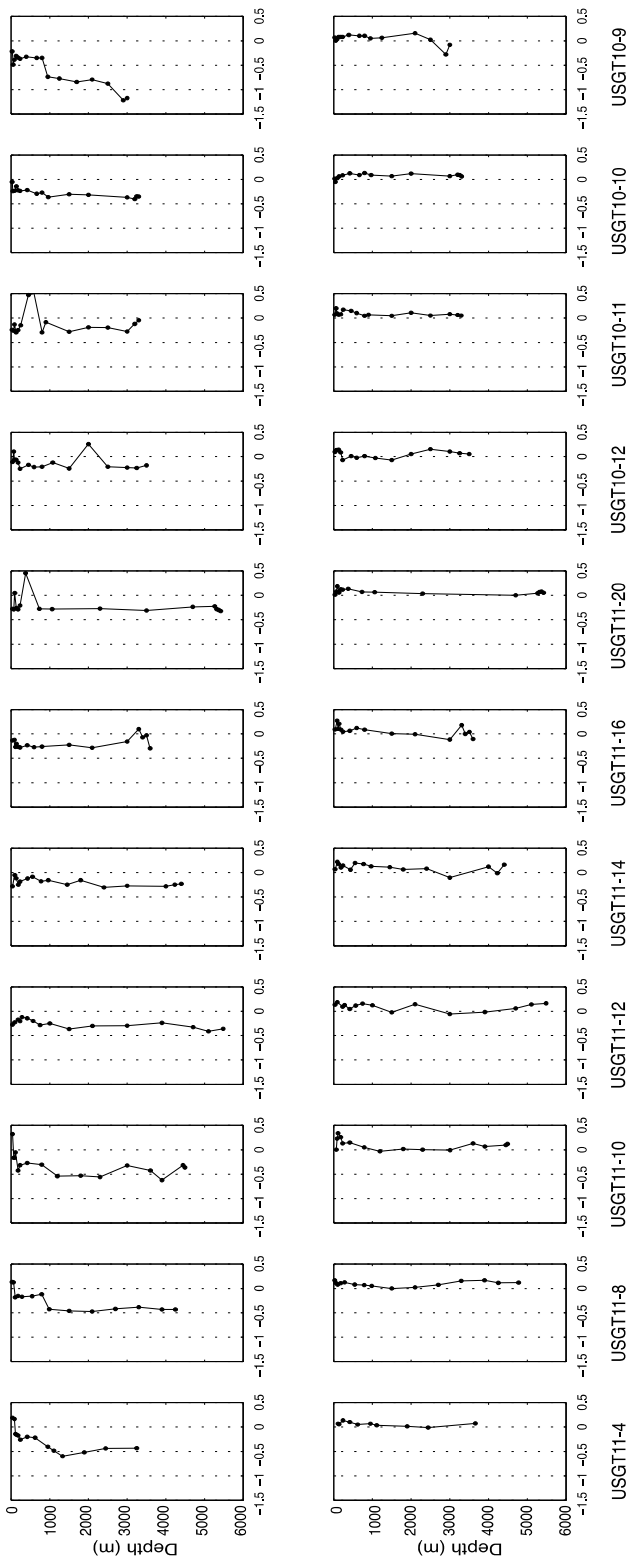

(\%\%) ㄹ!

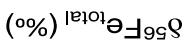




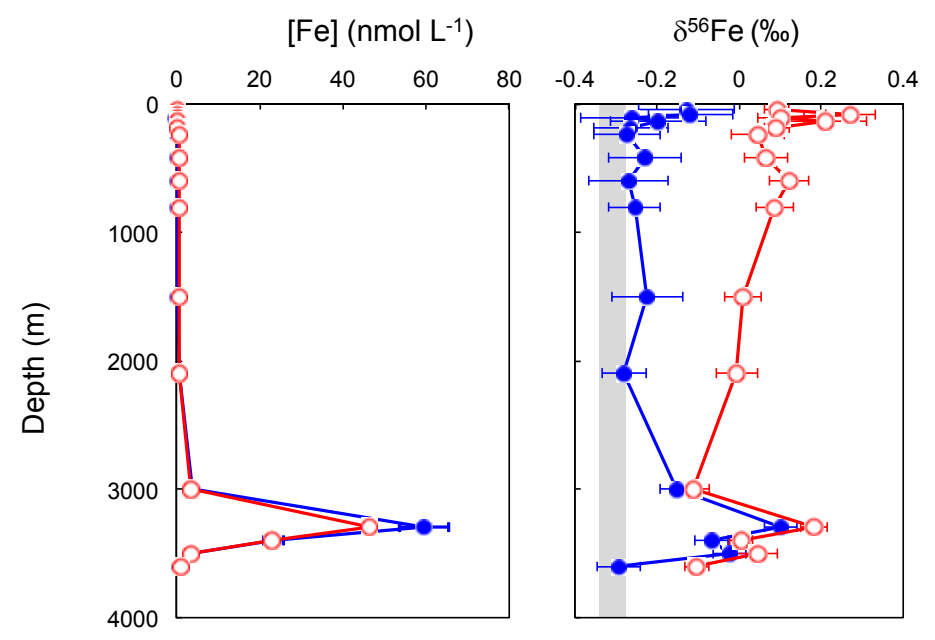

Figure 8. Particulate Fe concentration $([\mathrm{Fe}])$ and $\mathrm{Fe}$ isotope ratio $\left(\delta^{56} \mathrm{Fe}\right)$ at station USGT11-16, above the TAG hydrothermal field on the mid-Atlantic ridge. Labile Fe is shown in blue and total particulate Fe in red. Elevated Fe concentrations from $3000 \mathrm{~m}$ to $3500 \mathrm{~m}$ reflect the input of hydrothermal Fe into the plume. The grey bar represents the isotopic composition of TAG pure hydrothermal fluids (Severmann et al., 2004). 